\title{
Correction to: Supplier Internationalization Through Upgrading in Global Supply Chain: Evidence from the Garments Industry of Bangladesh
}

\author{
Mahmudul Hasan Fouji ${ }^{1}$ (i) $\cdot$ Imranul Hoque ${ }^{1}$ (I)
}

Published online: 3 September 2021

(c) Global Institute of Flexible Systems Management 2021

\section{Correction to: \\ International Journal of Global Business and \\ Competitiveness \\ https://doi.org/10.1007/s42943-021-00025-9}

Dear Readers,

The authors of this article found a possible conflict after publishing their article and, therefore, would like to add some texts and a reference in their paper. The changes in the paper are below:

In text (in sentence number five in the third paragraph on page no. 4 under literature review):

"Extant literature reveals that emerging country suppliers are motivated by their lead buyers to internationalize (Rana et al., 2021; Pananond, 2015). In their pioneering work, Rana et al. (2021) have shown the mechanisms of developing country suppliers' internationalization in collaboration with their lead buyer."

In reference section:

Rana, M. B., Allen, M. M., \& Servais, P. (2021). Supplier internationalization in the global apparel value chain from Bangladesh to Ethiopia: the buyers business model, institutions and entrepreneurial capability. In M. B. Rana, \& M.

The original article can be found online at https://doi.org/10.1007/ s42943-021-00025-9.

Mahmudul Hasan Fouji

foijii@gmail.com

Imranul Hoque

imran_du6@yahoo.com

1 Department of Marketing, Jagannath University, 9-10,

Chittaranjan Avenue, Dhaka 1100, Bangladesh
Allen (Eds.), Upgrading the Global Garment Industry (pp. 13-45). Edward Elgar Publishing.

The original article has been corrected.

We apologize for this mistake. 